- FINANSE I PRAWO FINANSOWE.

- Journal of Finance and Financial Law

Marzec/March 2018 • vol. 1(17): 37-47

https://doi.org/10.18778/2391-6478.1.17.04

\title{
THE INFLUENCE OF INSURANCE MARKET ON THE ECONOMIC DEVELOPMENT OF UKRAINE
}

\author{
Liudmyla Rybalchenko \\ Department of Applied Mathematics and Computer Science \\ University of Customs and Finance in Dnipro
}

\begin{abstract}
The level of economic development and the economic growth rates in Ukraine are very uneven. On the basement of production function were analyzed the factors of economic development in Ukraine. The influence of the level of the insurance development on its economic growth was considered.
\end{abstract}

Keywords: the production function, econometric model, economic development, generalized indicator, insurance.

JEL Class: C60, G22. 


\section{INTRODUCTION}

Modern economic development of the country often comes with risks that arise under the pressure of external and internal influences. It is a good worldwide practice to use insurance as an important instrument to minimalize or prevent some risks. Insurance helps to compensate the economic damages from different incidents, such as car accidents, financial risks, nature disasters and others. It is a necessary instrument not only for big or medium businesses, but also for smaller companies and private entities. Because of the fact that insurance stimulate accumulation of savings such as insurance benefits and transformation them into investments it is one of strategic parts of economy. The advantage of the insurance protection involves not only the property interests of people and different companies but also it has a great influence on macroeconomic development of the country.

Insurance business has a big variety of insurance services that underlines its necessity for modern Ukrainian economy. But at the same time the insurance market of Ukraine needs a sustainable governmental support to make an integrated insurance system with a glance to international trends and worldwide standards.

The current development of the Ukrainian insurance market is under the influence of the process of globalization and also the international integration. The preamble of the social and economic development should be the effective functioning of financial, insurance and the other markets. The insurance by itself it is an important element of the system of financial mechanisms to protection society from different incidents. But unfortunately all this justifies that Ukrainian insurance market still not in the condition to be the influential social and economic force.

A lot of problems in Ukraine are needed to have in-depth study towards identifying the positive and negative factors that occurs in the country. And also it is important to explore the reasons that restrain the development of Ukrainian insurance market by using modern economic and mathematic methods.

Among the scientific articles where the perspectives of the development of insurance market of Ukraine were researched can be noted the publications of V. Yukhymenko [Yukhymenko 2016: 44-48] and Y.Voinova [Voinova 2016: 27-32], and in the article of L. Rybalchenko [Rybalchenko 2013: 174-179] were researched the factors of economic development of Ukraine. At the same time, for today a lot of problems that are connected with the formation and the development of the insurance market remain unsolved. So such situation demands to find more effective solutions that will impact on its development.

The primary objective of this paper is to research the impact of insurance on the economic development of Ukraine by using the econometric models. 


\section{THE MAIN BODY OF THE ARTICLE}

The insurance market is a special sphere of monetary relations where the object of purchase and sale is an insurance protection that has both supply and demand. It is impossible to create an effective system of protection of the interests and property rights of some social groups or to maintain social stability in society and economic security of the country without the powerful functioning of the insurance market. Insurance it is also an important source of money accumulation for their further investments into the state economy. Insurance plays an important role in the economy of country because it greatly reduces budget expenditures for reimbursement of losses that were caused by emergencies, catastrophes, disasters (and also various of natural disasters) as well as protects business from unexpected financial risks and provides social support for citizens.

The insurance market of Ukraine in 2012-2016 still remained the trend of increasing the volume of insurance payments for all types of insurance. This trend can be observed in numerous statistic sources. We can see that the level of gross insurance payments in Ukrainian national currency (UAH) increased in 2016 by 63,52 per cent ( 35170,3 million UAH) in comparison with 2012 (21 508,2 million UAH), but at the same time if this indicator convert into dollars (USD) we can see that it decreased by 48,86 per cent in 2016 ( 1376,46 million USD) compared with 2012 (2691,55 million USD). The similar situation can be seen with the gross insurance benefits that increased by 71,61 per cent in 2016 (8 839,5 million UAH [National commission..., 2017]) in comparison with 2012 (5151 million UAH [National commission..., 2017]), but if this indicator convert into dollars we can see that it decreased by 46,33 per cent (345,95 million USD [Official website of the National Bank..., 2017]) in 2016 compared with 2012 (644,6 million USD) (p. 3).

The dynamic of the major indices of development of insurance in Ukraine are described in the tab. 1. Analysis of the available statistical data has shown that during the period of five years from 2012 to 2016 the number of insurance companies decreased by 132 . This may be attributed to the fact that on the insurance market of Ukraine remained only reliable insurance companies. The incomes of the insurance payments per capita in $2016(825,89 \mathrm{UAH}$ or 32,32 USD) increased by 1,75 times in comparison with 2012 (472,16 UAH or 59,09 USD), while the insurance benefits per capita in 2016 (207,58 UAH or 8,12 USD) increased by 1,84 times in comparison with 2012 (113,08 UAH or 14,15 USD) so here we can see a positive trend. The share of insurance benefits in insurance payments in $2013(16,23 \%)$ fell by 7,72 percentage points in comparison with $2012(23,95 \%)$ the reason for this was the reduction of 
a gross sum of insurance benefits, and in 2016 this share increased by 8,9 percentage points $(25,13 \%)$ in comparison with $2013(16,23 \%)$. It is considered that the optimum percentage value of this indicator is about 70 per cent [National commission..., 2017], but the Ukrainian insurance market still not meet the requirements of the world's leading economies.

Table 1. The dynamic of the main indices of development of the insurance market in Ukraine in 2012-2016

\begin{tabular}{|c|c|c|c|c|c|c|c|}
\hline Years & $\begin{array}{c}\text { Quantity of } \\
\text { insurance } \\
\text { companies }\end{array}$ & $\begin{array}{c}\text { Incomes of } \\
\text { insurance } \\
\text { payments } \\
\text { per capita, } \\
\text { UAH }\end{array}$ & $\begin{array}{c}\text { Incomes of } \\
\text { insurance } \\
\text { payments } \\
\text { per capita, } \\
\text { USD }\end{array}$ & $\begin{array}{c}\text { Insurance } \\
\text { benefits } \\
\text { per capita, } \\
\text { UAH }\end{array}$ & $\begin{array}{c}\text { Insurance } \\
\text { benefits } \\
\text { per capita, } \\
\text { USD }\end{array}$ & $\begin{array}{c}\text { Share of } \\
\text { insurance } \\
\text { benefits in } \\
\text { insurance } \\
\text { payments, \% }\end{array}$ & $\begin{array}{c}\text { Share of } \\
\text { insurance } \\
\text { payments } \\
\text { that were } \\
\text { given to } \\
\text { reinsurance, } \\
\%\end{array}$ \\
\hline 2012 & 442 & 472,16 & 59,09 & 113,08 & 14,15 & 23,95 & 11,87 \\
\hline 2013 & 407 & 630,96 & 78,94 & 102,40 & 12,81 & 16,23 & 30,51 \\
\hline 2014 & 382 & 623,53 & 52,46 & 118,00 & 9,93 & 18,92 & 36,25 \\
\hline 2015 & 361 & 695,41 & 31,83 & 189,44 & 8,67 & 27,24 & 33,33 \\
\hline 2016 & 310 & 825,89 & 32,32 & 207,58 & 8,12 & 25,13 & 36,02 \\
\hline
\end{tabular}

Source: Calculated by the author according to the data from the State Statics Service of Ukraine [National commission ..., 2017], [Official website of the National Bank ..., 2017], [State Statics..., 2017]

According to the data from the State Statics Service of Ukraine [State Statics..., 2017], [National commission ..., 2017] calculated that in 2016 the share of gross insurance payments in regard to gross domestic product (GDP) was $1,48 \%$ [Calculated be the author according to the data from Official website of the Ministry ..., 2017] that was less in comparison with 2013 (1,97\%). That clearly shows that during of that period the insurance market of Ukraine was under the impact of such the negative factors that were hampered its development.

Despite of the significant number of companies that were functioning on the insurance market of Ukraine in 2016, the main share of gross insurance payments $(99,9 \%)$ was accumulated by two hundred insurance companies that provided non-life insurance and among them the 85,9 per cent were belonged to the first 50 companies. To the biggest insurance companies in Ukraine belonged such companies as Cremen Insurance Company (2742,12 million UAH [National commission..., 2017] or 107,32 million USD [Calculated be the author according to the data from Official website of the National Bank..., 2017]), Ingosstrakh (1479,19 million UAH or 57,89 million USD) and AXA 
Strahuvanya (1400,43 million UAH or 54,81 million USD) the shares of which according to the level of insurance payment was 18,9\%. Analysing the structure of revenues of insurance payment according to the types of insurance in 2015 -2016 [National commission ..., 2017], we can see that the biggest part of shares of insurance benefits belongs to voluntary property insurance (tab. 2).

Property insurance it is one of the fields of insurance that is economically intended to compensate loses that were caused as a result of damages or destruction of the property in case when an insurance event occurs. The voluntary property insurance market of Ukraine still has its undeveloped potential. During the years of 2015-2016 the voluntary property insurance market had approximately 60 per cent $(57,5 \%)$ [Calculated by the author according to the data from National commission..., 2017] of insurance payments and among them only from 10,2 per cent to 12,1 per cent of insured risks (more detailed described in tab. 2), while in most developed countries this indicator is between 90 per cent and 95 per cent. Many Ukrainian scientists believe that the main problem that is hampered an increase of gross insurance payments is the lack of public's trust to insurance companies. And the main reasons for this are the low-quality of insurance services, low level of insurance benefits, the inadequacy of legislative framework, and also don't taking in account the interests and wishes of people during the insurance process.

Table 2. The structure of income of insurance payments in accordance with the types of insurance

\begin{tabular}{|l|c|c|}
\hline \multirow{2}{*}{\multicolumn{1}{|c}{ Types of insurance }} & \multicolumn{2}{c|}{ The structure of gross insurance payments, \% } \\
\cline { 2 - 3 } & 2015 & 2016 \\
\hline Non-life types of insurance: & 92,6 & 92,2 \\
\hline Voluntary personal insurance & 10,8 & 12 \\
\hline Voluntary property insurance & 57,5 & 57,5 \\
\hline - which includes insurance of financial risks & 12,1 & 10,2 \\
\hline Voluntary Third Party Liability Insurance & 7,7 & 6,6 \\
\hline Compulsory non-governmental insurance & 16,6 & 16 \\
\hline Life insurance & 7,4 & 7,8 \\
\hline Total (all types of insurance) & 100 & 100 \\
\hline
\end{tabular}

Source: Calculated by the author according to the data from National commission for the state regulation of financial services markets [National commission ..., 2017].

The amount of gross insurance benefits in 2016 increased by 18,3 per cent in comparison with the 2015. Increasing of the level of benefits is a reflection of the fact that there was a gradual transition to development of classic types 
of insurance. The structure of benefits [National commission..., 2017] according to the types of insurance is described in the tab. 3 .

Table 3.The structure of gross insurance benefits by the types of insurance

\begin{tabular}{|l|c|c|}
\hline \multirow{2}{*}{\multicolumn{1}{c}{ Types of insurance }} & \multicolumn{2}{c|}{ The structure of gross insurance benefits, $\%$} \\
\cline { 2 - 3 } & $2015 \mathrm{p}$. & $2016 \mathrm{p}$. \\
\hline Non-life types of insurance: & 93,9 & 95,3 \\
\hline Voluntary personal insurance & 18,4 & 19,4 \\
\hline Voluntary property insurance & 51,7 & 53,5 \\
\hline - which includes insurance of financial risks & 17,3 & 10,6 \\
\hline Voluntary Third Party Liability Insurance & 6,4 & 1 \\
\hline Compulsory non-governmental insurance & 17,5 & 21,3 \\
\hline Life insurance & 6,1 & 4,7 \\
\hline Total (all types of insurance) & 100 & 100 \\
\hline
\end{tabular}

Source: Calculated by the author according to the data from National commission for the state regulation of financial services markets [National commission..., 2017].

According to the Law of Ukraine on Insurance benefit it is a sum that is paid by insurer under the terms of the insurance contract when an insured event occurs.

The volumes of gross insurance benefits were increased in majority of different types insurance in 2016. The gross insurance benefits were increased in such types of insurance as voluntary personal insurance and voluntary property insurance and also of the compulsory non-governmental insurance.

The largest share of gross insurance benefits belonged to the voluntary property insurance which rose from 51,7 per cent in 2015 to 53,5 per cent in 2016 , but the benefits by the financial risks decreased by 6,7 percentage points, respectively to 2015 from 17,3 percentage points to 10,6 percentage points (tab. 3).

The voluntary liability insurance it is a reliable way to protect the property interests of legal persons or individuals that are obligated to pay for the damages that were caused to life, health or property of the third party. So as we can see from the tab. 3 the insurance benefits in 2016 comprised only 1 per cent, while in 2015 it was already 6,4 per cent.

Analysing the structure of gross insurance benefits in 2016 (Fig. 1) we can see the increasing of the percentage of such types of insurance as vehicle insurance $(43,3 \%)$, medical insurance $(15,7 \%)$, credit insurance $(12,9 \%)$, insurance of cargo and baggage $(4,6 \%)$ by which we can see increasing 
of insurance benefits. But the decreasing of percentage of insurance benefits in such types as insurance of financial risks $(9,6 \%)$, life insurance $(4,9 \%)$, property insurance $(1,7 \%)$ and other types of insurance $(7,3 \%)$.

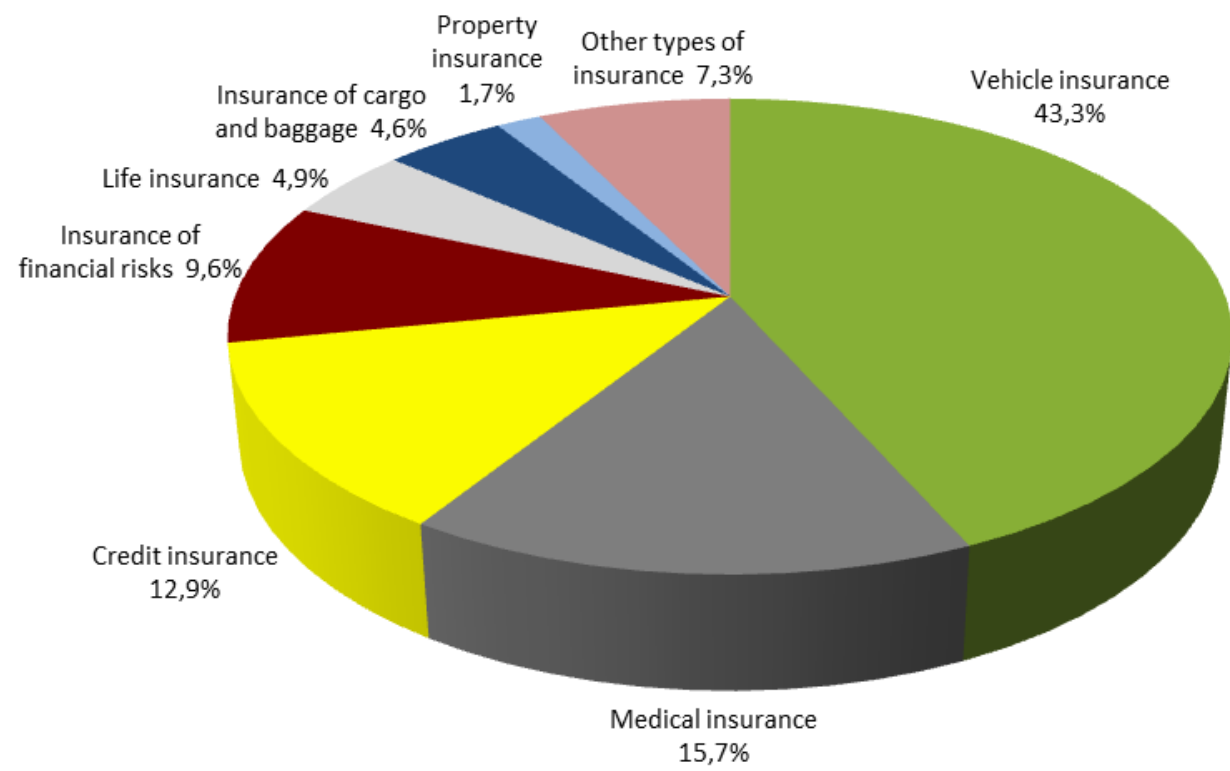

Figure 1. Shows the structure of gross insurance benefits by the main types of insurance in 2016

Source: Chart constructed by the author according to the data from the National Commission for State Regulation of Financial Services Markets [National commission..., 2017].

Reinsurance it is a system of economic relations between the insurers which allows the insurance company that has concluded insurance contracts to transfer the assumed risks to the other insurance companies - reinsurers. Reinsurance is a necessary requirement to ensure the financial stability of insurance operations and normal activity of any insurance environment and don't depends on the capital dimensions, reserve funds or other financial assets. The main sense of the relationships between the reinsurer and the other reinsurer company is the obligation of the reinsurer company to reimburse the share of indemnity payment to the insurance company caused by the insured events of their clients. The economic sense of reinsurance is the redistribution between the insurance companies of the created insurance fund.

Insurance payments that were paid to the reinsurance sector in 2016 in comparison with the relevant period of the previous year increased by 27,8 per cent or 2757,4 million UAH (107,92 million USD). 
The figure 2 shows the share of insurance payments that were given to reinsurance in other countries in 2016, describes that from the total sum of the paid shares of insurance payments in the reinsurance sector the biggest amount was paid to Great Britain $-16,5 \%$, China $-12,3 \%$, Germany $-10,5 \%$, India $-8,9 \%$, Poland $-8,6 \%$, Switzerland $-7,6 \%$ and Malaysia $-7,0 \%$.

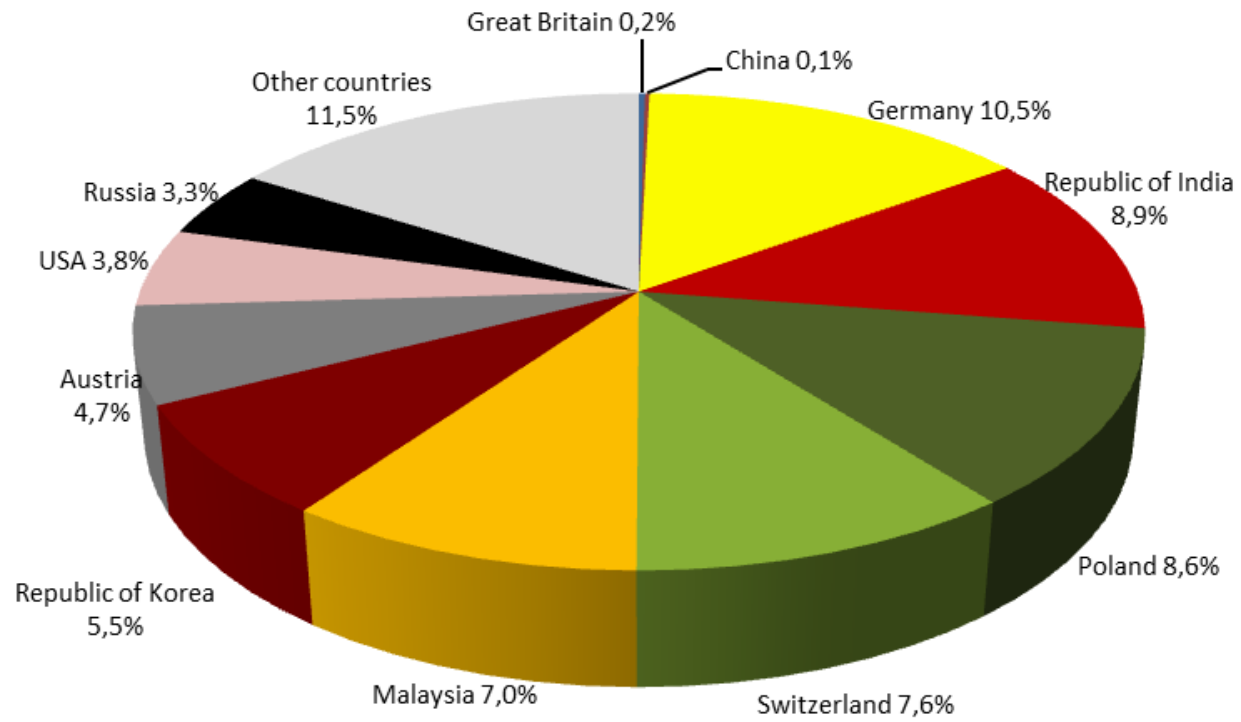

Figure 2. Shows the share of insurance payments that were given to reinsurance in some EU countries and other countries in the world in $2016(\%)$

Source: Chart constructed by the author according to the data from the National Commission for State Regulation of Financial Services Markets [National commission..., 2017].

\section{THE CONSTRUCTION OF THE MODEL OF THE LEVEL OF DEVELOPMENT OF INSURANCE IN UKRAINE BY USING MACROECONOMIC PRODUCTION FUNCTION}

Economic development of the country belongs to one of the most important concepts of macroeconomic theory. It characterizes the indicators of production of the main types of products which are basic for the development of the national economy.

The main indicators of the level of the economic development of the country are the GDP per capita (Gross Domestic Product), the NI (National 
Income) per capita, the sectoral structure of the national economy, production of major products per capita, quality of life and standards of living, the index of production efficiency and others.

It is known that to the economic development of the country the negative impact has an uncertainty of the market environment and the risk of economic activity of other companies under market relations. Because of the fact that insurance is an effective method of a rational risk management this determines its special role in the market-driven economy. For researching of influence of insurance to the economic growth was calculated and constructed the generalized indicator $S$ that means the development of insurance market in Ukraine in 2012 -2016 [National commission..., 2017], [Official website of the Ministry..., 2017] by using of the method of modified principal component [Rybalchenko: 2013] with the help of data analysis and statistical software - Stata.

For researching of influence of insurance on the economic growth of Ukraine is used such production function:

$$
y_{i t}=e^{\beta_{1} t+\beta_{2} \cdot s_{i t}} k_{i t}^{a}
$$

where:

$y_{i t}-$ gross regional product per capita,

$t-$ year,

$s_{i t} \quad-\quad$ generalized indicator of the development of insurance market in Ukraine,

$k_{i t} \quad$ - fixed assets in $t$-year per 1 employee,

$i \quad-\quad$ region of Ukraine.

According to the activity indicators of the insurance companies in Ukraine in 2012-2016 [National commission..., 2017] was constructed the combined regression (tab. 4) and evaluated the results of the model (1).As it may be seen from the tab. 4, all indexes of considered regression are significant with the level of significance less than $1 \%$ and the value of determination ratio is 0,92 that shows the positive statistic qualities of the constructed model (2):

$$
y_{i t}=e^{0,1531 t+0,1232 s_{i t}} k_{i t}^{0,7202}
$$

It is necessary to note that the value of elasticity of capital is equal to $a=0,7202$, and the value of ratio $\beta_{1}$ that characterises the frequency of neutral technical progress $\beta_{1}=0,1531$. The index $\beta_{2}=0,1232$ characterizes the level of development of insurance market in Ukraine, it is positive and as a result is 
statistically significant. So we received that the level of development of insurance market in Ukraine is materially affects to the economic development of the country.

Table 4. The results of calculation data of macroeconomic production function in Ukraine by taking into account the level of insurance development

\begin{tabular}{|c|c|c|c|c|c|c|c|}
\hline Source & |SS & & df & MS & & \multicolumn{2}{|c|}{$\begin{array}{c}\text { Number of obs }=74 \\
F(3,70)=118.54\end{array}$} \\
\hline Model & |12.72 & & 3 & 3.845 & & \multicolumn{2}{|c|}{ Prob $>F=0.0000$} \\
\hline Residual & 2.44 & & 70 & .0318 & & \multicolumn{2}{|c|}{ R-squared $=0.9203$} \\
\hline Total & 15.16 & & 73 & .1714 & & \multicolumn{2}{|c|}{ Root MSE = .1873 } \\
\hline \multicolumn{8}{|c|}{ Dependent variable: $\ln \left(y_{i t}\right)$} \\
\hline Variable & | Coef. & Std. Err. & & $\mathrm{t}$ & $\mathrm{P}>|\mathrm{t}|$ & \multicolumn{2}{|c|}{ [95\% Conf. Interval] } \\
\hline $\ln \left(k_{i t}\right)$ & $\mid .7202$ & .0671 & & 7.32 & 0.000 & .0892 & .3353 \\
\hline$t$ & $\mid .1531$ & .0235 & & 8.71 & 0.000 & .1507 & .1681 \\
\hline$s_{i t}$ & |.1232 & .0107 & & 6.83 & 0.000 & .0572 & .0868 \\
\hline const & 7.329 & .6125 & & 10.12 & 0.000 & 5.114 & 7.658 \\
\hline
\end{tabular}

Source: Calculated by the author according to the data from the State Statics Service of Ukraine [State Statics..., 2017], [National commission..., 2017], [Official website of the Ministry..., 2017].

\section{CONCLUSION}

The production function was constructed on the basis of indicators of the activity of the insurance market of Ukraine in 2012-2016 that gave the possibility to reveal the factors that have significant influence to economic growth in Ukraine.

The generalized indicator of development of insurance in Ukraine was constructed for researching of influence of insurance on the economic growth by using of modified principal component and included as a factor in the production function. As a result of evaluation of the indicators of the econometric model was received that the level of development of insurance market in Ukraine has a significant positive influence on the economic growth of the country.

The results of the investigation of the insurance market of Ukraine show the annual decreasing of the amount of insurance companies. There are several reasons that have negative effect on the development of the insurance market in Ukraine. Among them could be underlined such reasons as economic insecurity and political instability in the country, lack of a single governmental strategy of developing of insurance market, a low level of people's trust in 
the insurance companies and their services. It is possible to solve the described problems in such a way:

- formation of a single governmental strategy of developing of insurance market in Ukraine;

- adapting of the Ukrainian insurance legislation to the European Union norms and standards;

- providing an effective governmental control over insurers;

- popularizing of insurance products and services among Ukrainians and also familiarizing with their advantages.

That's way by solving all this problems it is possible to ensure annual stable development of insurance market in Ukraine. And as a result the insurance business will become a powerful tool of social security and also be a stable source of investment incomes.

\section{REFERENCES}

Rybalchenko L.V., 2013, Factors of economic development of Ukraine, Visnyk DSFA, no 1(29). Yukhymenko V.M., 2016, Insurance Services Market: Worldwide Tendencies and Perspectives of Development in Ukraine, „Investment: Practice and Experience”, no 3 [Electronic source] - available at: http://www.investplan.com.ua/pdf/3_2016/11.pdf.

Voinova Y.I., 2015, Competitiveness of Ukraine on the Worldwide Insurance Market in 2015, „Economic Reporter of Zaporizhzia State Engineer Academy”, no 3(03) [Electronic source] - Available at: http://www.zgia.zp.ua/gazeta/evzdia_2016_3_27.pdf.

National Commission for the State Regulation of Financial Services Markets, 2017 [Electronic source] - available at: http://www.nfp.gov.ua.

Official website of the Ministry of Finance of Ukraine, 2017 [Electronic source] - available at: http://index.minfin.com.ua.

Official website of the National Bank of Ukraine. Official average exchange rates of Hryvnia against Foreign Currencies, 2017 [Electronic source] - available at: https://bank.gov.ua/files/Exchange_r.xls.

State Statics Service of Ukraine, 2017 [Electronic source] - available at: https://ukrstat.org.

\section{WPŁYW RYNKU UBEZPIECZENIOWEGO NA EKONOMICZNY ROZWÓJ UKRAINY}

Poziom rozwoju gospodarki i tempo wzrostu gospodarczego na Ukrainie są bardzo nierównomierne. Na podstawie funkcja produkcji zbadano czynniki rozwoju gospodarczego na Ukrainie. Przeanalizowano wpływ poziomu rozwoju ubezpieczeń na wzrost gospodarczy.

Słowa kluczowe: funkcja produkcji, model ekonometryczny, rozwój gospodarczy, "zbiorczy” indykator rozwoju, ubezpieczenia. 